シンポジウムI：気管食道科領域におけるレーザーの応用

\title{
3.レーザー適応の問題点
}

\section{*法 貴昭}

\section{Symposium I : Laser Medicine and Surgery, Basic and Clinical in Broncho-esophagology \\ 3. The Problems of Laser Surgery for Tracheo-esophageal Diseases}

Akira Hohki, M.D.

Department of Otolaryngology, School of Medicine, Kobe University, Kobe

When laser is adapted to the region of trachea and esophagus, it must have merits in comparison with usual scalpel and other new therapeutic methods developed by modern engineering: For the application of laser to the region of trachea and esophagus, following five items were examined.

1. Characteristic mark in this region

2. Characteristic mark of laser in comparison with other new therapeutic methods

3. Various kinds of lasers to be adapted to this region, and these merits and demerits

4. Applicable diseases

5. The problems and the side effects

In conclusion, laser is very effective therapeutic method to many kinds of tracheal and esophageal diseases and has special merits in comparison with other therapeutic methods. However, we must grasp enough it's characteristics and recognize the limitation to it's adaptation.

Key words : laser, trachea, esophagus

\section{は じめに}

気管食道領域にレーザーを適用するには，従 来のメスによる治療や，科学技術の発達により 開発された新しいレーザー以外の治療法等に比 ベてメリットがなければ意味がない。そのため に, 以下の 5 項目について検討を加えた。I . 気管食道領域の部位的特徵, II.レーザーの他 の治療に比較しての特徵, III. この領域に使用 しうるレーザーの種類, IV. 適用疾患, V. そ の際に生ずる副作用と問題点。

*神戸大学医学部耳鼻咽喉科

\section{I . 部位的特徵}

レーザーをはじめ凍結手術, 超音波吸引手術, マイクロ波手術などを頭頸部領域に適用する場 合,もつとも適用が容易であるのは顔面, 外耳, 口唇, 口腔, 頸部表面であり, いずれも直接的 視診，触診が可能な部位である(部位(1))。次に 適用しやすいのが外耳道, 鼻腔, 開空された上 顎洞と上咽頭，中咽頭である(部位(2))。さらに 上咽頭, 下咽頭, 喉頭, 気管, 食道の順となる (部位(3))。すなわち, 下咽頭, 喉頭, 気管, 食 道は頭頸部ではもっとも深部に属し, 診断, 治 療の困難な領域と言える。レーザーを用いて治 
$\mathrm{CO}_{2}$ LASER 541 cases

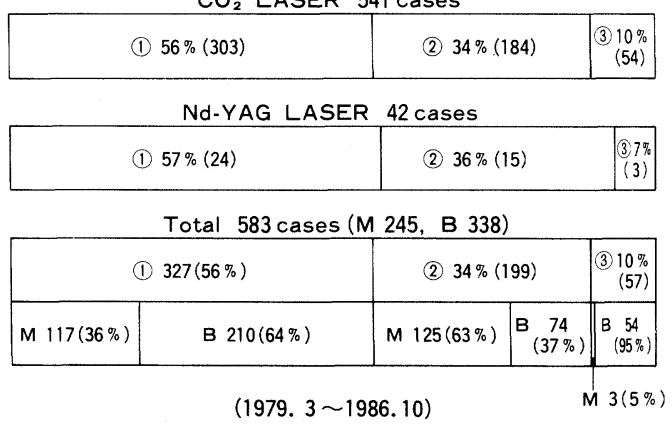

図 1 レーザーを適用した疾患の部位

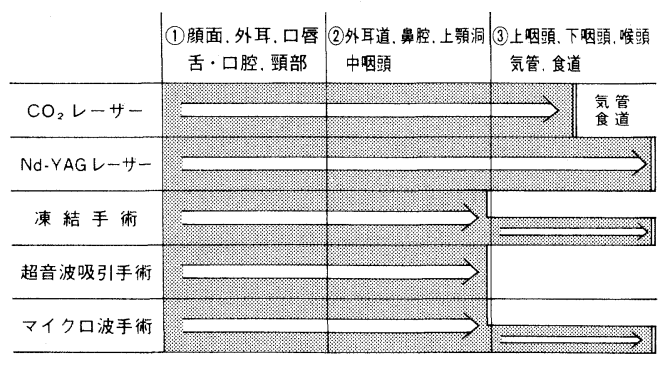

適用部 位

図 2 各種治療法の適用部位

表 1 各種レーザーの長所と短所

\begin{tabular}{|c|c|c|c|}
\hline & & 長 所 & 短 所 \\
\hline $\mathrm{CO}_{2}$ レーザー & & $\begin{array}{l}\text { 粘膜, 病巣の切開, 切除 } \\
\text { 病单の即時蒸散 } \\
\text { レーザーマイクロサージェリー }\end{array}$ & $\begin{array}{l}\text { 止血能が劣る } \\
\text { 深部病巣にやや適用困難 }\end{array}$ \\
\hline \multirow[t]{2}{*}{ Nd-YAGレーザー } & 接 触 型 & $\begin{array}{l}\text { 粘膜, 病巣の切開，切除 } \\
\text { 病巣の凝固壤死 }\end{array}$ & 止血能が劣る \\
\hline & 非接触型 & $\begin{array}{l}\text { 病巣の凝固，蒸散 } \\
\text { レーザーマイクロサージェリー } \\
\text { 狭い部位，深部に適用可能 } \\
\text { 止 血 }\end{array}$ & $\begin{array}{l}\text { 凝固範囲の制御やや困難 } \\
\text { 蒸散能が劣る }\end{array}$ \\
\hline 光化学療法 & & $\begin{array}{l}\text { 病巣のみを治療しうる深部 } \\
\text { の病巣に適用可能 }\end{array}$ & 深在性腫瘍に効果不良 \\
\hline
\end{tabular}

療した自験例は，1979年 3 月～1986年10月まで 583例であるが，このうち(1)の部位は327例（56 \%)，(2)の部位は199例（34\%）で，これに対し (3)の部位は 57 例（10\%）に過ぎない。

\section{II.レーザーの特徴 ${ }^{11}$}

前述の (3)の部位を治療する場合, 通常の鋼メ スでは非常に柄の長いものを要し，またそれに 従って操作も困難となってくる。エネルギーの 伝達方法が問題となる。凍結手術, 超音波吸引 手術，マイクロ波手術では，プローベと呼ばれ る.先端部分で手術を行うが，超音波吸引手術は (3)部位に適用可能な細く，長いプローベは現存 していない。また凍結手術やマイクロ波手術で は，この部位にも適用可能なプローベが開発さ れているが，高エネルギーを送ることは困難で

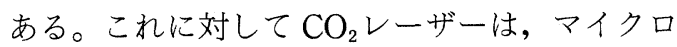
マニュプレーターを用いて空間を直線的に上咽
頭，下咽頭，喉頭までは光としてエネルギーを 送ることができ顕微鏡と連動して微細な手術も 無血的に容易に行うことができる2),3) $\left(\mathrm{CO}_{2}\right.$ レー ザー用のファイバーは現在開発中)。さらにNdYAGレーザーは，オプティカルファイバーを 通じて高エネルギーを送ることができ，しかも 観察のための光をも同時に送ることが可能なの で，内視鏡にも組込んで用いることができ，気 管, 食道領域では極めて秀れた能力を発揮する。

\section{III. 使用するレーザーの種類}

代表的なものは $\mathrm{CO}_{2}$ レーザー (波長 $10.6 \mu \mathrm{m}$ ) である ${ }^{4)}$ 。その長所は粘膜の切開, 切除, 病巣の 即時蒸散, laser microsurgery が可能な点であ る。この場合，通常の鋼メスによる方法と比較 して術者の視野の妨げにならない点, 非接触性 であることが秀れている。短所は止血能が劣る こと，気管，食道のような深部病巣にはやや適 
用困難であることである。次に, Nd-YAGレー ザー(波長 $1.06 \mu \mathrm{m}$ ) である。接触型と非接触型 がある。ともに microsurgery が可能である。接 触型では粘膜の切開, 切除, 接触型では病巣の 凝固, 蒸散に秀れている5 。細いファイバーを通 じてエネルギーを送り，かつ同時に観察のため の光も送ることができるので気管，食道領域に は秀れた効果を期待しうる。しかし, 接触型で は止血能が劣ること, 非接触型では凝固範囲の 制御がやや困難であること, 蒸散能が劣ること などの欠点がある。最後は光化学療法である6)。 本療法は腫瘍組織のみを選択的に治療すること ができること, 気管, 食道領域に容易に適用で きる点が長所である。短所は深在性腫崵に効果 が不良なことである。

\section{IV. 適応疾患}

以上の事項から，気管食道領域における現状 でのレーザーの適応は自ずと決定される。

1）良性疾患

a) 気管, 喉頭, 食道の瘢痕狭窄8) : 痏痕組 織の除去には $\mathrm{CO}_{2}$ レーザーを用いると殆んど 出血なしに蒸散することができる。しかし, 気 管, 食道では $\mathrm{CO}_{2} レ$ レ゙ーを適用することが困 難なことが多いので, この場合はヤグレーザー の通常型を用いると良い。レーザー光を管腔の 縌軸に平行に照射して, 痏痕を少しずつ凝固さ せて, 吸引等で除去, また照射して凝固, 吸引 をくり返して少しずつ除去するのが良い。あま り大きな出力を用いない方が良い。出力が大き いと凝固が予期しない部分にまで及び, 後日穿 孔を来たす危険性がある。この場合，ヤグレー ザーは観察のための光をもファイバーを通じて 送ることができるので便利である。疲痕狭窄の 場合, 単にレーザーで除去しただけでは, 再び 瘢痕形成を来たす可能性があるので, 術後シリ コンステント等の使用が必要な場合が多い。レ ーザーを用いると出血が殆んどなく, 明視下に 手術ができるので危険性が少ない。

b）炎症性肉芽，ポリープ9),10),11)：鋼メスや 鉗子による切除に比較しての特徵は, 出血が少 ないため術野の観察が容易で, 術後の出血, 浮 腫の心配のないことである。 c）囊胞：特に舌根囊胞に有用である。一般 に, 鋼メスや鉗子による切除では, 出血等によ り十分な視野が得られず，囊胞の取り残しを来 たしやすく，しばしば再発を認める。Laser microsurgery を行うと, 囊胞壁の蒸散および原 発部位の確認が容易で, 取り残しが少なく, 再 発することが少ない。

d）血管性病変 (血管腫, リンパ管腫） ${ }^{12)}$ : 血管腫に対しては, $\mathrm{CO}_{2}$ レーザーはときとして 出血を来たすことがあるので注意を要する。可 及的に defocused beam で病巣を凝固して後, 蒸散する方が良い。その点, ヤグレーザーの方 が容易に凝固させることができる。いずれにし ても, 術後の出血がないようにしなければなら ない。リンパ管腫では, 囊胞状限局性リンパ管 腫は $\mathrm{CO}_{2}$ レーザーが特に有効である。

e ) 乳頭腫 ${ }^{13)}$ : 特に若年性乳頭腫症 ${ }^{14)}$ には 有力な治療手段となる。凍結手術のごとく, 術 後に浮腫を来たすことがないために，気管切開 の必要がないこと。また腫瘍部分のみ蒸散する ことができるので，他の部分を傷害しないので 腫湯の播種の危険性が少なく，また出血が少な いことが特徴である。喉頭, 咽頭では, $\mathrm{CO}_{2} レ ー$ ザー，気管ではヤグレーザーを用いると良い。

2 ）癌前駆症 ${ }^{15), 16), 17) ~}$

主に白板症, 乳頭腫で部位的には喉頭が対象 である。本疾患は悪性腫瘍ではないので，放射 線治療や化学療法や喉頭摘出術の対象とはなら ない。しかし, 通常の laryngomicrosurgery で は摘出困難な疾患で, レーザーによる治療がも つとも適している。Laser microsurgeryにより 声門下の病変をも処置することができる。しば しば再発するので, 数回の手術が必要なことが 多い。喉頭癌前駆症は癌化する確率が高いので, そのつど十分に病理組織検査を行う必要があ る。

3 ）悪性腫瘍 ${ }^{18), 19,20)}$

喉頭, 気管, 下咽頭, 食道領域の悪性腫瘍に 対して，レーザーを用いて根治的治療を行うこ とは，種々の困難を伴う。レーザー治療がもつ と行いやすい舌癌と比較するとよく理解でき る。舌癌21)では, レーザーにより健常組織をも含 めて en bloc に摘出可能であり, 病理組織学的 
に検索して完全に摘出されたか否かを確認する ことができる。しかも，術後容易に再照射が可 能であり，また経過観察には視診，触診を直接 行うことができる。

これに対し気管食道領域癌では，手術には全 身麻酔が必要で，支持喉頭鏡，気管支鏡，食道 鏡を用いてもレーザーで en bloc に腫瘍を摘出 することが困難であること，そのため病理組織 学的検索も十分行いえないこと，また広範囲に レーザー照射を行うと穿孔の危険がある（著者 は食道癌症例に対して凍結手術を行い，腫瘍は 消失したが，過凍結のため気管食道瘻を来たし た経験がある)。またレーザー照射は通常上方か らの一方向からしか行うことができない。その 上，術後の観察も舌癌のように容易ではなく， 視診もファイバーや間接鏡を通じて観察するの みである。このことから，現状ではレーザーが 主体となるような根治治療の対象となりうるも のは初期喉頭癌のみである。他は併用治療や， 集学的治療のうちの腫瘍減量の一治療法と考え るのが妥当である。

以上，気管食道領域に対するレーザー治療に ついて述べたのは，喉頭鏡，食道鏡，気管支鏡 を用いる，いわゆる非経皮的治療についてであ るが，喉頭截開術，喉頭部分切除術，頸部皮膚 切開した後の気管や食道に対するレーザーの応 用については, 前述のごとくレーザーの特徵を 用いて切除，蒸散に応用することができる。

\section{V.レーザー治療における問題点と副損傷}

気管食道領域における非経皮的レーザー治療 では，経皮的治療と異なり病巣を en bloc に摘 出することは困難である。このため, 術前の部 位診断, 術中の観察, 術後の経過観察は特に正 確さを必要とする。しかし, 本領域では視診, 触診，レントゲン診のうち，触診にはあまり期 待できないので，視診が中心となる。その視診 にしても，通常は間接鏡かファイバースコープ による間接的方法である。直視下に観察するに は，直達鏡下，気管支鏡，食道鏡を必要とし， 簡単に行うことができない。また患者にとって の負担も軽くない。その上，触診の方向が上方 の一方向からに限られている。このため, 診断
の精度にも問題がある。

レーザーの照射も上方拉よび側方からのみ で，(1)の部位のごとく十分な照射方向が得られ ない。またくり返しの手術が簡単に行えない。 さらにレーザー治療に伴う副損傷がある。

レーザー手術の副作用のうち，本領域でもっ とも重大なものは，高エネルギーを狭い腔内に 投入することによる障害である。

1）発 煙：特に $\mathrm{CO}_{2}$ レーザーを用いて 組織を蒸散した場合に生じる。これに対しては 吸引によって排煙すること，排煙が十分でない 場合は，照射を中止する必要がある。

2) 発 火 ${ }^{22)}$ : 狭い腔に対し, 高エネルギ 一のレーザーを照射した場合（Joul = watt $\times$ time), 対象の病巣にうまく照射されていれば, その部の凝固, 蒸散されるが，これが他の部位， 特に挿管チューブに当たると発火する可能性が ある。また支持喉頭鏡，気管支鏡，食道鏡の金 属部分に当たるとその部が高熱となり，接触し ている組織を損傷する可能性がある。 $\mathrm{CO}_{2}$ レー ザーの場合，湿綿や水分を含んだガーゼで被覆 することにより防止することができる。しかし， ヤグレーザーの通常型の場合には，水を透過し たり，透明なチューブを透過して予期しない部 分にエネルギーが吸収されるので，特に注意を 要する。

一方, 金属や白色部はレーザー光を反射して， 他の部分にエネルギーが吸収される可能性があ る。

いずれにしても，正しい照射を行うことが基 本である。

3) 誤照射：挿管チューブ等の人工物に対 する直接および反射による誤照射および病巣以 外の健常部にレーザーを照射することがあり， 注意を要する。

4）過咶なエネルギーの投与：管腔を形成 する臟器に，レーザーを過剩に照射した場合， 組織の過剰の壊死を来たして穿孔を起こすこと があり注意を要する。特にヤグレーザーの場合, エネルギーが照射部より周辺に散乱するので, 予想以上の組織変化を来たすことがあり，注意 を要する。

術後に生じる副損傷のうちもつとも重大なも 


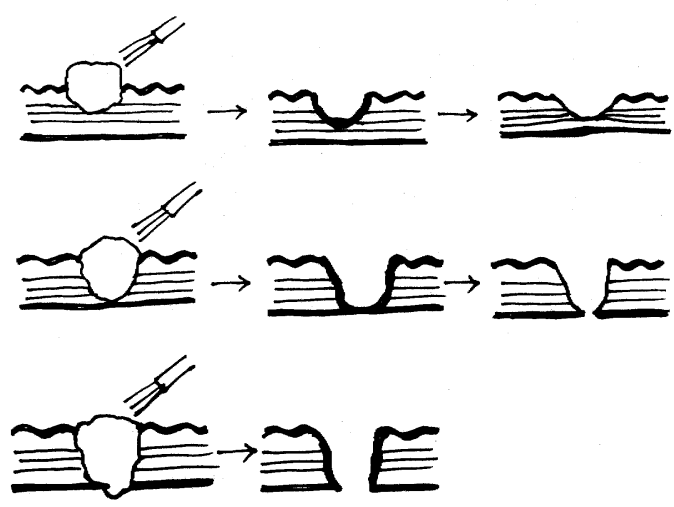

図 3 穿孔の成立

のは穿孔，瘦孔，出血である。もちろんこれは 術中にも起こり得る副損傷である。

1）穿孔，2）瘻孔・気管, 食道のごとき管腔 臓器では，常に念頭に入れておかなければなら ない副作用である。特に，腫崵が粘膜層のみな らず，筋層まで及んでいるような場合は，注意 しなければならない。術中に穿孔を生じる可能 性はもちろんのことであるが，非接触型のヤグ レーザーを高エネルギーで照射した場合, 初め に照射野の周辺まで凝固層が拡がり，次いで照 射野に深い欠損を生じることから, 術中, 術後 に穿孔を生じる可能性がある。

$3)$ 出血: $\mathrm{CO}_{2}$ レーザーでは, 組織を次 々と蒸散することができるので，比較的太い血 管を損傷して出血を来たす可能性がある。顕微 鏡と連動して, laser microsurgery を行うと, 良い視野が得られ，防止することができる。

4) 浮 腫 : 非接触型ヤグレーザーでは, 照射野の周辺に浮腫を生じることがある。

5 ）瘢痕：比較的軽度である。

\section{VI. 結 論}

気管，食道領域に対するレーザーは極めて有 用な治療手段であり，他の治療法にない特徵を もっている。ただしこれらの特徵を十分把握し て用いることが重要であり，またその限界をも 知っておく必要がある。

\section{文献}

1）法貴昭：頭頸部がんの集学的治療. 癌と化学療
法, 13：1777-1783, 1986.

2 ) Strong, M. S. et al.: Laser surgery in the larynx. Ann. Otol. Rhinol. Laryngol. 81:791798,1972 .

3 ) 三橋重信：炭酸ガスレーザー外科.日耳鼻, 78 : 1244-1248, 1975.

4 ）法貴昭・他：頭頸部悪性腫瘍に対する炭酸ガス レーザーによる治療.耳鼻臨床，75：740-750, 1982.

5 ）中原朗・他：各種レーザー治療における改良と 工夫（特に接触法, 穿刺法と照射法の比較につい て). 日本レーザー医学会誌，5:185-196，1985.

6）加藤治文 - 他：肺癌に対する光化学療法の問題 点とその対策. 日本レーザー医学会誌，5：103108, 1985.

7) Wile, A. G. et al. : Laser photoradiation therapy of cancer following hematoporphrin sensitization. Laser Surg. Med., 2 : 163-168, 1982.

8 ）三橋重信・他：耳鼻咽喉科領域におけるレーザ 一手術の可能性と限界. 耳鼻臨, $74: 2767-2782$, 1981.

9 ) 三橋重信：レーザー手術.耳鼻と臨床，25補2： 364-377, 1979.

10）村上嘉彦：レーザー手術.耳鼻と臨床，25補2： 358-363, 1979.

11) Freche, ch. et al. : Laser Tokyo 81 (Atsumi, K. \& Nimsakul, N.) (Japan Society for Laser Medicine) Inter Group, p. 6-13, Tokyo 1981.

12）法貴昭・他：口腔内血管性病変（血管腫拈よび リンパ管腫)の治療. JOHNS, 2 : 639-645, 1986.

13）法貴昭・他：Oral florid papillomatosis および 類似疾患について. JOHNS, 2 : 633-637, 1986.

14）高島荘二・他：若年性（小児）喉頭乳頭腫の治 療.耳鼻臨, $75 ： 691-699,1982$.

15) Roodenburg, J. L. N. et al.: Treatment of superficial lesions of the oral mucosa with carbon dioxide laser. A report of 58 cases with 5 years follow up. J. Exp. Clin. Cancer Res., 3 : 283-286, 1983.

16) Horch, $\mathrm{H}$. H. et al. : $\mathrm{CO}_{2}$ laser treatment of oral dysplastic precancerous lesions. A preliminary report. Laser Surg. Med., 2 : 179-185, 1982.

17）法貴昭・他：白班症(口腔内)について. JOHNS, $2: 651-655,1986$.

18）井上鐵三：Laser 光による頭頸部癌の治療.日 本レーザー医学会誌, $5 ： 22-29,1984$.

19）平野実： $\mathrm{CO}_{2}$ レーザーによる頭頸部がんの治 療.がんの臨床, $31: 673-678,1985$.

20）黒野祐一・他：頭頸部腫瘍に対するレーザー手 術の検討.耳鼻臨床，75：1525-1533, 1982.

21）法貴昭・他：舌癌のレーザーによる治療. JOHNS, $2: 675-678,1986$.

22) Ossoff, R. H. et al. : $\mathrm{CO}_{2}$ laser in otolaryngology head and nech surgery. A retrospective 
日気食会報，38（2），1987

analysis of complications. Laryngoscope, 93 : 1287-1289, 1983.

(別刷請求： $=650$ 兵庫県神戸市中央区楠町7-5-2

神戸大学医学部耳鼻咽喉科

法貴昭 